\title{
METODE LISTENING TEAM DAN MODEL AUDITORY INTELLECTUALLY REPETITION (AIR) DALAM PENGAJARAN MENYIMAK DI SEKOLAH DASAR
}

\author{
Dilla Fadhillah \\ Universitas Muhammadiyah Tangerang \\ dillafadhillah@umt.ac.id
}

\begin{abstract}
Abstrak
Metode dan model pengajaran Bahasa saat ini sangat bervariasi, sehingga para pengajar dapat leluasa memilih metode dan model pembelajaran yang cocok digunakan dalam proses belajar Bahasa Indonesia. Para pengajar dapat menerapkan metode dan model pembelajaran yang sesuai dengan keterampilan berbahasa. Pada keterampilan menyimak, metode yang dapat digunakan yaitu Metode Listening Team dan Model Auditory Intellectually Repetition (AIR). Metode dan model pembelajaran bahasa Indonesia tersebut merupakan metode dan model yang terdapat dalam pembelajaran kooperatif (Cooperative Learning). Dua metode pembelajaran kooperatif tersebut memiliki sasaran untuk mengasah keterampilan menyimak siswa Sekolah Dasar. Oleh karena, metode Listening Team dan Model Auditory Intellectually Repetition (AIR) dapat merangsang memfokuskan perhatian siswa dan mengasah kemampuan berpikir kritis siswa Sekolah Dasar.
\end{abstract}

Kata Kunci: Listening Team, Auditory Intellectually Repetition

\section{A. PENDAHULUAN}

Pendidikan di Indonesia dari waktu ke waktu semakin berkembang pesat, hal tersebut ditandai oleh beberapa hal: a) angka lulusan di tingkat universitas semakin banyak, b) kurikulum mengalami perubahan dengan penyempurnaan di berbagai aspek, c) semakin banyak pilihan sekolah menawarkan keunggulan yang dimilikinya, d) semakin bervariasinya metode pembelajaran. Terkait dengan metode pembelajaran, saat ini terdapat puluhan metode pembelajaran yang berkembang di Indonesia. Pembelajaran kooperatif adalah salah satu yang memiliki banyak jenis metode dan model pembelajaran di dalamnya. 
Lingua Rima: Jurnal Pendidikan Program Studi Bahasa dan Sastra Indonesia

Vol. 9 No. 1 Juli 2020

Menurut Isjoni bahwa cooperative learning adalah suatu model pembelajaran dimana sistem belajarnya bekerja dalam kelompok-kelompok kecil yang berjumlah 4-6 orang secara kolaboratif sehingga dapat merangsang siswa lebih bergairah dalam belajar (2010: 15). Proses pembelajaran yang berkelompok diharapkan akan lebih efektif dan mempermudah siswa dalam memahami serta memecahkan masalah. Terdapat karakteristik cooperative learning menurut Hamdani (2010: 31) adalah: 1) Setiap anggota memiliki peran, 2) Terjadi hubungan interaksi langsung di antara siswa, 3) Setiap anggota kelompok bertanggung jawab atas belajarnya dan juga teman-teman sekelompoknya, 4) Guru membantu mengembangkan keterampilanketerampilan interpersonal kelompok, 5) Guru hanya berinteraksi dengan kelompok saat diperlukan.

Pada cooperative learning terdapat metode listening team dan model auditory Intellectually Repetition (AIR). Menurut Hamruni, Listening Team merupakan sebuah cara membantu siswa agar tetap terfokus dan siap selama pembelajaran berlangsung (2011: 166). Proses pembelajaran dengan metode ini lebih memusatkan kegatan dengan cara mendengarkan penjelasan seorang guru. Peserta didik bersama-sama fokus dengan kelompoknya mendengarkan materi yang disampaikan. Sedangkan model Auditory Intellectually Repetition (AIR) terdiri dari tiga komponen yaitu Auditory. Menurut Huda bahwa "pikiran auditoris lebih kuat daripada yang tidak kami sadari”. Cara belajar auditorial adalah cara belajar yang mengakses segala jenis kata dan bunyi (2014:289-90). Gaya belajar jenis ini menitikberatkan pada indera pendengaran. Indera pendengaran bekerja sangat optimal pada model ini untuk memperoleh materi dengan sempurna.

Selanjutnya komponen kedua Menurut Shoimin (2014:29) Intellectually bermakna belajar harus menggunakan kemampuan berpikir (mind on) dengan mengkonsentrasikan pikiran dan berlatih menggunakannya melalui bernalar, menyelidiki, mengidentifikasi, menemukan, mencipta, mengkonstruksi, memcahkan masalah, dan menerapkan. Sedangkan komponen ketiga Shoimin (2014:29), Repetition merupakan pengulangan dengan tujuan memperdalam dan memperluas pemahaman siswa yang perlu dilatih melalui pengerjaan soal, pemberian tugas, dan kuis. Karakteristik yang dimiliki oleh kedua metode di atas, bahwa metode ini sangat efektif digunakan dalam proses pembelajaran Bahasa Indonesia khususnya keterampilan menyimak di Sekolah Dasar. 
Lingua Rima: Jurnal Pendidikan Program Studi Bahasa dan Sastra Indonesia

Vol. 9 No. 1 Juli 2020

\section{B. Metode Listening Team}

Har (2016:499) bahwa pembelajaran Listening Team (Tim Pendengar) merupakan salah satu model pembelajaran cooperatif learning yang dimaksudkan untuk mengaktifkan siswa dengan membagi siswa berkelompok dan memberi tugas yang berbeda kepada masing-masing kelompok tersebut Sesuai dengan namanya model ini berjalan dengan pengelompokan siswa di dalam kelas selama proses pembelajaran. Siswa bersama kelompoknya memecahkan masalah bersama dengan cara mengutamakan pendengaran. Listening Team (Tim pendengar) strategi ini membantu peserta didik untuk tetap terkonsentrasi dan fokus dalam pelajaran/perkuliahan yang menggunakan metode ceramah. Strategi ini bertujuan membentuk kelompok-kelompok yang mempunyai tugas atau tanggung jawab tertentu berkaitan dengan materi pelajaran Menurut Zaini dkk (2008:30). Strategi Listening Team dengan cara fokus mendengarkan pemberian materi, akan membuat siswa lebih mudah paham dan mendapat informasi lebih banyak.

Menurut Suprijono (2017) Pembelajaran dengan metode listening team diawali dengan pemaparan materi pembelajaran oleh guru. selanjutnya guru membagi kelas menjadi kelompokkelompok. Setiap kelompok mempunyai peran masing-masing (2017:115). Misal, di dalam satu kelas dibagi menjadi 4 kelompok. Kelompok pertama merupakan kelompok penanya, kelompok kedua dan kelompok ketiga adalah kelompok penjawab. Kelompok kedua merupakan kumpulan orang yang menjawab berdasarkan perspektif tertentu, sementara kelompok ketiga adalah kumpulan orang yang menjawab dengan perspektif yang berbeda dengan kelompok kedua. Perbedaan ini diharapkan memunculkan diskusi yang aktif yang ditandai oleh adanya proses dialegtika berpikir, selanjutnya hingga mereka menemukan pengetahuan struktural. Kelompok keempat adalah kelompok yang bertugas me review dan membuat kesimpulan dari hasil diskusi. Pembelajaran diakhiri dengan penyampaian berbagai kata kunci atau konsep yang telah dikembangkan oleh peserta didik dalam berdiskusi.

\section{Efektivitas Metode Listening Team}

Metode Listening Team merupakan model pembelajaran kooperatif yang menuntut siswa untuk berpikir kritis, yang setiap kelompoknya memiliki tugas yang berbeda. Sehingga, siswa dapat berperan aktif dalam mengemukakan pendapatnya. diawali dengan pemaparan materi pembelajaran oleh guru. Selanjutnya guru membagi kelas menjadi kelompok-kelompok 
Lingua Rima: Jurnal Pendidikan Program Studi Bahasa dan Sastra Indonesia

Vol. 9 No. 1 Juli 2020

Kelompok pertama merupakan kelompok penanya, kelompok kedua dan kelompok ketiga adalah kelompok penjawab. Kelompok keempat adalah kelompok yang bertugas menelaah dan membuat kesimpulan dari hasil diskusi. Menurut Suprijono (2017:120-121) langkah-langakah metode tim pendengar:

1. Bagilah peserta didik menjadi 4 tim dan berilah tim-tim ini dengan tugas-tugas sebagai berikut:

a. Tim A sebagai penanya, tugas merusmuskan pertanyaan

b. Tim B sebagai pendukung, tugas menjawab pertanyaan yang didasarkan pada poinpoin yang disepakati (membantu dan menjelaskannnya mengapa demikian)

c. Tim C sebagai penentang, tugas mengutarakan poin-poin yang tidak disetujui atau tidak bermanfaat dan menjelaskan mengapa demikian.

d. Tim D sebagai penarik kesimpulan, tugas menyimpulkan hasil.

2. Penyaji pemaparkan laporan hasil penelitiannya, setelah selesai beri waktu kepada tiap kelompok untuk menyelesaikan tugas sesuai dengan perannya masing-masing (h.120121).

Metode listening team efektif karena siswa berkesempatan untuk aktif dalam pembelajaran. Para siswa diwajibkan untuk menyimak tim penanya dan tim penjawab harus menjawab pertanyaan tim penanya dengan tepat. Hasil menyimak di-review dan disimpulkan oleh para siswa sehingga siswa dapat memfokuskan pikiran dan dapat merangsang kemampuan berpikir kritis siswa. Selain itu, siswa dapat mengungkapkan ide/gagasannya serta dapat mengembangkan kemampuan siswa untuk berbicara dalam mengemukakan pendapat. Akan tetapi, terdapat kekurangan pada metode listening team yaitu 1) menghabiskan waktu yang cukup lama, 2) sulit menumbuhkan sikap komunikatif.

\section{Efektifitas Model Auditory, Intellectually, Repetition (AIR)}

Model pembelajaran Auditory, Intellectually, Repetition merupakan salah satu model pembelajaran yang dapat membuat siswa merasa nyaman dan gembira dalam belajar. Suherman dalam Shoimin (2014:29) Auditory bermakna bahwa belajar haruslah melalui mendengarkan, menyimak, berbicara, presentasi, argumentasi, mengemukakan pendapat, dan menanggapi. Mendengar merupakan salah satu aktivitas belajar, karena tidak mungkin informasi yang 
Lingua Rima: Jurnal Pendidikan Program Studi Bahasa dan Sastra Indonesia

Vol. 9 No. 1 Juli 2020

disampaikan secara lisan oleh guru dapat diterima dengan baik oleh siswa jika tidak melibatkan indera telinganya untuk mendengar. Guru diharapkan bisa memberikan bimbingan pada siswa agar pemanfaatan indera telinga dalam KBM dapat berkembang secara optimal sehingga interkoneksi antara telinga dan otak bisa dimanfaatkan secara optimal.

Menurut Meier dalam Huda (2014:290) Intelektual bukan lah "pendekatan tanpa emosi, rasionalistis, akademis, dan terkotak-kotak. Kata 'intelektual' menunjukan apa yang dilakukan pembelajar dalam pikiran mereka secara internal ketika mereka menggunakan kecerdasan untuk merenungkan suatu pengalaman dan menciptakan hubungan, makna, rencana, dan nilai dari pengalaman tersebut". Intelektual ialah kecerdasan. Dengan kecerdasan siswa mampu menyelasaikan manasalah dalam pikiran mereka sendiri secara internal. Repetition merupakan perulangan bunyi yang bermakna pendalaman, perluasan, pemantapan materi melalui pemberian tugas kepada siswa. Pada memberi pengulangan, agar pemahaman siswa lebih mendalam dan lebih luas guru dapat memberika tugas atau kuis. Dengan diberikan tugas, siswa akan terbiasa menyelesaikan persoalan-persoalan materi tersebut. Sedangkan diberikan kuis siswa akan senantiasa siap dalam menghadapi tes ujian. Dengan adanya latihan dan pengulangan akan membantu dalam proses mengingat.

Berdasarkan pendapat tersebut disimpulkan bahwa pembelajaran Auditory, Intellectually, Repetition merupakan model pembelajaran yang menuntut siswa aktif di kelas. Auditory yaitu belajar dengan mendengar, menyimak, berbicara, presentasi, argumentasi, mengemukakan pendapat, dan menanggapi. Intellectually yaitu kecerdasan menunjukan apa yang dilakukan pembelajar dalam pikiran mereka secara internal ketika mereka menggunakan kecerdasan untuk merenungkan suatu pengalaman dan menciptakan hubungan, makna, rencana, dan nilai dari pengalaman. Repetition ialah pengulangan yang brmakna pendalaman, perluasan, pemantapan dengan cara peserta didik dilatih melalui pemberian tugas atau kuis.

Menurut Shoimin (2014) langkah-langkah model Auditory, Intellectually, Repetition sebagai berikut:

1. Siswa dibagi menjadi beberapa kelompok, masing-masing kelompok 4-5 siswa.

2. Siswa mendengarkan dan memerhatikan penjelasan dari guru.

3. Setiap kelompok mendiskusikan tentang materi yang mereka pelajari dan menuliskan hasil diskusi tersebut dan selanjutnya untuk dipresentasikan di depan kelas. 
Lingua Rima: Jurnal Pendidikan Program Studi Bahasa dan Sastra Indonesia

Vol. 9 No. 1 Juli 2020

4. Saat diskusi berlangsung, siswa mendapat soal atau permasalahan yang berkaitan dengan materi.

5. Masing-masing kelompok memikirkan cara menerapkan hasil diskusi serta dapat meningkatkan kemampuan mereka untuk menyelesaikan masalah.

6. Setelah selesai berdiskusi, siswa mendapat pengulangan materi dengan cara mendapatkan tugas atau kuis untuk tiap individu (hal 30).

Dari paparan di atas dapat dijelaskan bahwa langkah-langkah pembelajaran Auditory, Intellectually, Repetition ialah siswa dibagi menjadi beberapa kelompok setiap kelompok terdiri dari 4 sampai 5 siswa. Setelah guru membagi kelompok siswa mendengarkan dan memerhatikan penjelasan guru. Setiap kelompok mendiskusikan tentang materi yang mereka pelajari dan menuliskan hasil diskusi tersebut dan selanjutnya untuk dipresentasikan di depan kelas. Saat diskusi berlangsung, siswa mendapat soal atau permasalahan yang berkaitan dengan materi. Masing-masing kelompok memikirkan cara menerapkan hasil diskusi serta dapat meningkatkan kemampuan mereka untuk menyelesaikan masalah. Langkah yang terakhir yaitu siswa mendapat pengulangan materi dengan cara mendapatkan tugas atau kuis untuk tiap individu.

Menurut Shoimin (2014:30) kelebihan model Auditory, Intellectually, Repetition sebagai berikut:

1. Siswa lebih berpastisipasi aktif dalam pembelajaran dan sering mengekspresikan idenya.

2. Siswa memiliki kesempatan lebih banyak dalam pengetahuan dan keterampilan secara komperhensif.

3. Siswa dengan kemampuan rendah dapat merespon permasalahan dengan cara mereka sendiri.

4. Secara interinsik termotivasi untuk memberikan bukti atau penjelasan.

5. Siswa memiliki pengalaman banyak untuk menemukan sesuatu dalam menjawab permasalahan (hal 30).

Efektivitas model Auditory, Intellectually, Repetition ialah siswa aktif dalam pembelajaran dan sering mengekspresikan idenya. Siswa memiliki banyak kesempatan dalam pengetahuan secara luas, dengan kemampuan yang rendah siswa dapat merespon permasalahan dengan 
Lingua Rima: Jurnal Pendidikan Program Studi Bahasa dan Sastra Indonesia

Vol. 9 No. 1 Juli 2020

caranya sendiri. Dengan metode ini siswa sangan termotivasi untuk memberikan bukti atau penjelasan dalam materi pembelajaran. Banyak pengalaman untuk menemukan dalam menjawab permasalahan. Akan tetapi terdapat kekurangan model Auditory, Intellectually, Repetition yaitu sebagai berikut:

1. Membuat dan menyiapkan masalah yang bermakna bagi siswa bukanlah pekerjaan yang mudah. Upaya memperkecilnya guru harus mempunyai persiapan yang lebih matang sehingga dapat menemukan masalah tersebut.

2. Mengemukakan masalah yang langsung dapat dipahami siswa sangat sulit sehingga banyak siswa yang mengalami kesulitan bagaimana merespons permasalahan yang di berikan.

3. Siswa dengan kemampuan tinggi bisa merasa ragu atau mencemaskan jawaban mereka (Shoimin 2014:30).

Kekurangan metode Auditory, Intellectually, Repetition ialah guru harus mempunyai persiapan yang matang sebab menyiapkan masalah yang bermakna bukanlah pekerjaan yang mudah. Banyak siswa yang mengalami kesulitan untuk merespon permasalahan yang diberikan karna kurangnya pemahaman dari materi pembelajaran. Siswa dengan kemampuan yang tinggi bisa merasa ragu atau mencemaskan jawaban mereka.

\section{E. SIMPULAN}

Berdasarkan hasil analisis metode Listening Team dan model Auditory, Intellectually, Repetition. Kedua metode ini sangat cocok diterapkan dalam proses pembelajaran Bahasa Indonesia khususnya keterampilan menyimak. Metode Listening Team memiliki tahapan yang melatih kemampuan mendengarkan tidak hanya secara individu, tetapi juga melatih kemampuan mendengarkan secara berkelompok serta memiliki tingkat kesukaran berbeda antara individu yang tergabung di dalamnya. Sedangkan untuk model Auditory, Intellectually, Repetition melatih kemampuan menyimak dengan tiga cara berbeda. Cara pertama dengan Auditory yaitu mendengarkan, melatih kemampuan mendengarkan siswa secara berulang dengan memberikan informasi yang beragam. Cara kedua Intellectually yaitu kecerdasan atau kemampuan berpikir siswa dalam memecahkan masalah yang diperolehnya ketika menerima informasi. Siswa dilatih tidak hanya mendengarkan informasi tetapi juga dilatih bagaimana caranya memecahkan masalah menggunakan kecerdasan yang dimilikinya. Cara ketiga Repetition yaitu 
Lingua Rima: Jurnal Pendidikan Program Studi Bahasa dan Sastra Indonesia

Vol. 9 No. 1 Juli 2020

pengulangan atau pendalaman dilakukan oleh siswa agar semakin menguasai informasi yang sudah diperolehnya dari proses menyimak/mendengarkan.

\section{F. DAFTAR PUSTAKA}

Hamdani, M.A. 2010. Strategi Belajar Mengajar. PUSTAKA SETIA. Bandung.

Hamruni. 2011. Strategi Pembelajaran. Insan Madani. Yogyakarta.

Har, Erman. (2016). Model Pembelajaran Kooperatif Tipe Listening Teamdalam Upaya Meningkatkan Hasil Belajar Ekologi Hewan. Jurnal Universitas Bung Hatta. No. 1 ISSN 2528-5742.

Huda, Miftahul, (2014). Model-model Pengajaran Pembelajaran. Yogyakarta : Pustaka Pelajar.

Isjoni. 2010. Cooperative Learning. ALFABETA. Bandung.

Juliana. (2017). Pengaruh Penggunaan Model Pembelajaran Listening Team Terhadap Kemampuan Berpikir Kritissiswa Kelas VII SMP Negeri 4 Bireuen. Jurnal Pendidikan Geografi Universitas Almuslim, No. 3 ISSN 2085-6172.

Rahayuningsih, Sri, (2017). Penerapan Model Pembelajaran Matematika Model Auditory, Intellectually, Repetition (AIR). Malang : Program Studi Pendidikan Matematika, Universitas Wisnuwardhana Malang.

Shoimin, Aris, (2014). 68 Model Pembelajaran Inovatif. Yogyakarta : Ar-Ruzz Media.

Silberman, M. (2014). Active Learning 101 Strategi Pembelajaran. Yogyakarta :PUSTAKA INTAN MADANI.

Suprijono, Agus. (2017). Cooperative Learning. Yogyakarta: Pustaka Pelajar.

Zaini, Hisyam, dkk. (2008). Strategi Pembelajaran Aktif. Yogyakarta: Insan Madani. 